\title{
A Standing Investment Court under TTIP from the Perspective of the CJEU
}

\author{
Szilárd Gáspár-Szilágyi* \\ PluriCourts, University of Oslo, Norway \\ szilard.gaspar-szilagyi@jus.uio.no
}

\begin{abstract}
This article critically assesses the feasibility of the recently proposed Investment Court System (ICS) under the envisaged Transatlantic Trade and Investment Partnership (TTIP), from the perspective of the Court of Justice of the European Union (CJEU). It is argued that an ex ante assessment of the ICS by the CJEU would likely result in several incompatibilities between the ICS and EU law, since insufficient safeguards exist guaranteeing that the ICS will not interfere with EU fundamental rights and the CJEU's exclusive jurisdiction to deliver binding interpretations of EU law. Moreover, it is not yet certain whether an incompatibility exists with Article 344 TFEU or with substantive EU values. Furthermore, no preliminary reference mechanism is envisaged with a binding ruling of the CJEU and even if such a system were included, it is uncertain whether the ICS could refer a question to the CJEU.
\end{abstract}

\section{Keywords}

TTIP - Investment Court System - compatibility with EU Law - ex ante review

\section{Setting the Stage}

There is a Hungarian saying according to which 'it is not easy to please both the cabbage and the goat that wants to eat the cabbage'. It seems that the European Commission in its November 2015 Proposal for a standing Investment Court System (ICS) ${ }^{1}$ under the Transatlantic Trade and Investment Partnership (TTIP) had to please more than just the 'cabbage' and the 'goat'. Besides the clear split between civil society's opposition to

\footnotetext{
* The article was written while the author was a Postdoctoral Researcher at the Amsterdam Centre for European Law and Governance (ACELG), University of Amsterdam, funded by ACCESS Europe. The author would like to thank Stephan Schill, Nanette Neuwahl and the reviewers of The Journal of World Investment and Trade for their constructive comments.

1 European Commission, 'TTIP Draft Text on Chapter II - Investment' (2015) $<$ http://trade.ec.europa.eu/doclib/docs/2015/november/tradoc_153955.pdf> $>$ accessed 31 March 2016 [hereinafter: the Proposal].
} 
investor-State dispute settlement (ISDS) and the corporate world's support for it, ${ }^{2}$ there is also the United States as the other contracting party that will have to agree to such a mechanism and a fairly 'selfish' ${ }^{3}$ Court of Justice of the European Union (CJEU) that is not that keen on sharing its jurisdiction with other international courts.

In this context it is no wonder that the European Commission came out with a 39-page proposal that moves away from ad hoc investor-State arbitration to a permanent $\mathrm{ICS}^{4}$ made up of a Tribunal of First Instance and an Appeal Tribunal. ${ }^{5}$ The Proposal includes detailed provisions on the definitions of 'investment', ${ }^{6}$ the standards of treatment afforded to foreign investors, ${ }^{7}$ the rights of the contracting parties to regulate in the public interest, ${ }^{8}$ rules on transparency, ${ }^{9}$ alternative methods of dispute resolution, ${ }^{10}$ the initiation of ISDS proceedings, ${ }^{11}$ and specific rules on the set-up and functioning of a two-tier system. ${ }^{12}$

The Tribunal shall not have jurisdiction to determine the legality of a measure that is alleged to constitute a breach of TTIP 'under the domestic law of the disputing Party', ${ }^{13}$ and prior to the initiation of proceedings, the claimant shall deliver a notice to the European Union (EU) requesting a determination of the respondent if the alleged breach was committed by the EU or one of its Member States. ${ }^{14}$ Furthermore, the domestic law of the Parties shall not be part of the applicable law to the investor-State dispute ${ }^{15}$ and the Tribunal is required to follow the 'prevailing interpretation' of a domestic legal provision 'made by the courts or authorities of that Party'. ${ }^{16}$ Moreover, the meaning given to the relevant domestic law by the Tribunal shall not be binding on the domestic courts and authorities, and for greater

\footnotetext{
${ }^{2}$ European Commission, 'Online Public Consultation on Investment Protection and Investor-to-State Dispute Settlement (ISDS) in the Transatlantic Trade and Investment Partnership (TTIP)' (13 January 2015) SWD(2015) 3 final <http://trade.ec.europa.eu/doclib/docs/2015/january/tradoc_153044.pdf> accessed 31 March 2016.

3 This term is used by Bruno de Witte, 'A Selfish Court? The Court of Justice and the Design of International Dispute Settlement beyond the European Union’ in Marise Cremona and Anne Thies (eds), The European Court of Justice and External Relations Law. Constitutional Challenges (Hart 2014) 33.

4 The idea for a standing Investment Court appeared several months before the Proposal. See European Commission, 'Concept Paper: Investment in TTIP and Beyond - the Path for Reform. Enhancing the Right to Regulate and Moving from Current Ad Hoc Arbitration towards an Investment Court' <http://trade.ec.europa.eu/doclib/docs/2015/may/tradoc_153408.PDF> accessed 31 March 2016.

${ }^{5}$ Proposal (n 1) s 3, arts 9-10.

${ }^{6}$ Proposal (n 1) 1-2 ('Definitions Specific to Investment Protection').

${ }^{7}$ ibid s 2, arts 3-5 and Annex I.

8 ibid s 2, art 2.

9 ibid s 3, art 18.

${ }^{10}$ ibid s 3, sub-s 2.

11 ibid s 3, sub-s 3 .

12 ibid s 3, sub-s 4.

13 ibid s 3, art 13(4).

14 ibid art 5(1)-(3).

15 ibid art 13(3).

16 ibid.
} 
interpretational certainty the Services and Investment Committee may adopt decisions interpreting the Investment Protection or the Investment Resolution provisions of TTIP, decisions that are binding on the ICS. ${ }^{17}$ Nevertheless, final awards issued by the Tribunal shall be binding between the disputing parties and shall not be subject to appeal, review, setaside, annulment or any other remedy. ${ }^{18}$

Even though the ongoing negotiations of TTIP, especially its ISDS clause, have been met with academic ${ }^{19}$ and serious public criticism, ${ }^{20}$ this article does not seek to take sides in this debate and argue in favour or against ISDS. Instead, this article looks at whether the ICS meets the criteria set out in the CJEU's case-law on the compatibility of international agreements and international courts with the EU legal order.

The present article is structured in the following way. Section 2 provides a short overview of the CJEU's role as the constitutional 'architect' of the relationship between EU and international law. Section 3 discusses the CJEU's case-law on the conditions a proposed international (extra-EU) tribunal must meet in order to be compatible with the EU legal order. The compatibility of the proposed ICS with EU law is then assessed in light of these conditions in Section 4. Section 5 concludes with recommendations on how to make the proposed ICS compatible with EU law.

\section{The CJEU 'Building’ the Relationship Between EU and International Law}

From a public international law perspective the CJEU is a regional court tasked with the supervision of several international agreements creating a regional economic organisation, namely the EU. ${ }^{21}$ Such a view, however, downplays the importance of the CJEU as the 'constitutional architect' of a 'new legal order of international law' ${ }^{22}$ that has its own constitutional 'charter'. ${ }^{23}$

Unlike traditional regional or international courts, the CJEU is much more akin to federal type constitutional courts. It is not only charged with the application, interpretation

\footnotetext{
${ }^{17}$ ibid art 13(4)-(5).

18 ibid art 30.

19 One of the most vocal critics is Gus Van Harten, 'A Report on the Flawed Proposals for Investor-State Dispute Settlement (ISDS) in TTIP and CETA', Osgoode Legal Studies Research Paper No 16/2015 (2015) <http://papers.ssrn.com/sol3/papers.cfm?abstract_id= 2595189> accessed 31 March 2016.

${ }^{20}$ The idea of ISDS was met with protests all around Europe, most importantly the massive rally in Berlin which gathered 250.000 people. See Chris Johnston, 'Berlin anti-TTIP Trade Deal Protest Attracts Hundreds of Thousands’ (The Guardian, 10 October 2015) <http://www.theguardian.com/world/2015/oct/10/berlin-antittip-trade-deal-rally-hundreds-thousands-protesters> accessed 31 March 2016.

${ }^{21}$ Szilárd Gáspár-Szilágyi, 'The CJEU: An Overzealous Architect of the Relationship Between the European Union Legal Order and the International One?' [2016] Revista de Drept Constituțional (forthcoming).

${ }^{22}$ CJEU, Case 26/62, Van Gend en Loos v Nederlandse Administratie [1963] ECR 1, 12.

${ }^{23}$ CJEU, Opinion 1/91 (EEA I) [1991] ECR I-60709, para 21.
} 
and validation of secondary EU legal instruments, and with the interpretation of primary EU law, ${ }^{24}$ but it has also established itself as a constitutional-type court. In this latter capacity, the CJEU has developed principles and mechanisms (primacy, direct effect) to define the relationship between the EU and Member State legal orders, ${ }^{25}$ it is engaged in a constant dialogue with the Member State courts through the preliminary reference mechanism under Article 267 TFEU, and most importantly for our purposes, it has also created an intricate case-law on the relationship between the EU legal order and international law. ${ }^{26}$

When defining the relationship between EU law and international law, the CJEU is faced with a constitutional dilemma. ${ }^{27}$ On the one hand, under Articles 19(1) TEU and 267 TFEU, the CJEU has the ultimate authority over the interpretation, application and validity of EU law; it is the guarantor of the autonomy of EU law from intrusions coming from the Member State legal orders or international law. ${ }^{28}$ On the other hand, under Article 3(5) TEU the EU shall pursue multiple forms of international cooperation and shall contribute to the development of international law. This duty implies that the EU should favour initiatives that strengthen the judicialization of international law. ${ }^{29}$ As a preliminary illustration, according to the CJEU an international agreement, which provides for its own system of courts, is in principle compatible with EU law. ${ }^{30}$ Nevertheless, the present article will illustrate that the CJEU lays down extremely high standards, which in practice results in the CJEU almost never submitting itself to the decisions of an envisaged international court.

The CJEU in many ways acts in a fashion similar to national constitutional courts that try to safeguard their own domestic constitutional values from the intrusions of $\mathrm{EU}$ or international law. The safeguarding of the EU legal order from the intrusions of international

\footnotetext{
24 art 267 TFEU; art 19(2) TEU. See Gáspár-Szilágyi (n 21).

${ }^{25}$ CJEU, Van Gend en Loos (n 22); Case 6/64 Costa v ENEL [1964] ECR 585; Case 11/70, Internationale Handelsgessellschaft [1970] ECR 1125.

${ }^{26}$ Opinions on the relationship between EU law and extra-EU courts: CJEU, Opinion 1/91 (EEA I) [1991] ECR I-60709; Opinion 1/09 (European Patent Court) [2011] ECR I-1137; Opinion 2/13 (Accession to the ECHR) [2014] EU:C:2014:2454. Case-law on the effects of international agreements in the EU legal order: CJEU, Case 181/73, Haegeman v Belgium [1974] ECR 449; Case 270/80, Polydor Limited v Harlequin Records [1982] ECR 329; Case C-366/10, Air Transport Association of America [2011] ECR I-13755. Case-law on the effects of international decisions in the EU legal order: CJEU, Joined Cases C-120/06 P and C-121/06 P, FIAMM and Fedon [2008] ECR I-6513. Case-law on the effects of customary international law in the EU legal order: CJEU, Case C-162/96, Racke [1998] ECR I-3655; Case C-286/90, Anklagemyndigheden v Poulsen [1992] ECR 6019.

${ }^{27}$ CJEU, Opinion AG Jääskinen in Joined Cases C-402/12 and C-403/12 P, Vereniging Milieudefensie [2014] EU:C:2014:310, para 1.

${ }^{28}$ See Gisèle Uwera, 'Investor-State Dispute Settlement (ISDS) in Future EU Investment-Related Agreements: Is the Autonomy of the EU Legal Order an Obstacle?' (2016) 15 PICT 102, 111-13.

${ }^{29}$ De Witte (n 3) 34.

${ }^{30}$ CJEU, Opinion 1/91 (n 26) paras 40-70; Opinion 1/09 (n 26) para 74; Opinion 2/13 (Accession to the ECHR) (n 26) para 182.
} 
law has followed various intertwining strands in the CJEU's case-law. In the first line of such cases, the CJEU focused on the protection of the autonomy of the EU legal order and laid down a set of core values that form part of the 'very foundations' of the EU legal order. ${ }^{31}$ These core foundations include EU fundamental rights, ${ }^{32}$ the internal allocation of powers within the $\mathrm{EU}^{33}$ and the exclusive jurisdiction conferred on the CJEU by the EU treaties. ${ }^{34}$ Many of the EU's core values were set out in opinions of the CJEU delivered under Article 218(11) TFEU. This provision provides Member States, the European Parliament, the Council or the Commission with the possibility to obtain the opinion of the CJEU 'as to whether an [international] agreement envisaged is compatible with the Treaties', in order to forestall any future complications. ${ }^{35}$ This procedure is not mandatory and has to be requested ex ante, prior to the agreement becoming binding on the EU. ${ }^{36}$ However, in case of an adverse opinion by the CJEU, the envisaged agreement may not enter into force 'unless it is amended or the [EU] Treaties are revised'. ${ }^{37}$

In the second line of such cases, the CJEU employs protectionist measures when faced with the internal application and enforcement of EU international obligations, after the agreements have entered into force. The Court resorts to measures that protect EU law, when secondary EU measures need to be reviewed for their conformity with international law ${ }^{38}$ or it restricts exceptions that concern non-directly-effective international agreements. ${ }^{39}$ This defensive stance is also illustrated by the EU's political bodies, which have included no-direct effect clauses in recently negotiated or concluded international agreements by the

${ }^{31}$ CJEU, Joined Cases C-402/05 P and C-415/05 P, Kadi and Al Barakaat International Foundation v Council and Commission (Kadi I) [2008] ECR-06351, para 282.

32 ibid para 283.

${ }^{33}$ CJEU, C-459/03, Commission v Ireland (Mox Plant) [2006] ECR I-4635.

${ }^{34}$ CJEU, Kadi (n 31) para 282; CJEU, Opinion 1/91 (n 26) paras 35 and 71; Mox Plant (n 33) para 123. Prior to the Lisbon Treaty Article 220 EC Treaty (now Article 19(1) TEU) provided: 'The Court of Justice shall ensure that in the interpretation and application of this Treaty the law is observed.'

${ }^{35}$ See also CJEU, Opinion 2/94 (WTO Agreement) [1996] ECR I-1759, para 3; Opinion 1/09 (n 26) para 47.

${ }^{36}$ Koen Lenaerts and others, EU Procedural Law (OUP 2014) 558.

37 ibid 550-60. The US Supreme Court and federal courts cannot deliver such opinions, since a case brought before them has to be factually and legally well-founded, a present dispute which has not ended. See Gregory C Sisk, Litigation with the Federal Government. Cases and Materials (2nd edn, Foundation Press 2008) and US Supreme Court, Commonwealth of Massachusetts v Mellon [1923] 262 US 447.

38 Szilárd Gáspár-Szilágyi, 'EU International Agreements Through a US Lens: Different Methods of Interpretation, Tests and the Issue of "Rights"' (2014) 39(5) EL Rev 601, 609-15; Mario Mendez, 'The Legal Effects of Community Agreements: Maximalist Treaty Enforcement and Judicial Avoidance Techniques’ (2010) 21 EJIL 83.

39 Szilárd Gáspár-Szilágyi, 'The Relationship between EU Law and International Agreements. Restricting the Fediol and Nakajima Exceptions in Vereniging Milieudefensie’ (2015) 52(4) CMLR 1059. 
EU. ${ }^{40}$ This second line of cases has been amply discussed in legal academia ${ }^{41}$ and shall not form part of the current discussion.

It follows from the above discussion that the CJEU prefers a pluralist understanding of the relationship between EU and international law. Under 'legal pluralism' states will still apply international law as the higher norm, as long as it does not conflict with certain core constitutional principles of the domestic legal order. ${ }^{42}$ In other words, the CJEU will show solicitude for international agreements 'only insofar as these agreements and their various institutional arrangements do not undermine the constitutional architecture of the EU' ${ }^{43}$ Therefore, the compatibility of the proposed ICS with EU law 'raises foundational questions of EU constitutional law that go beyond questions of EU external relations law and EU competence. $^{44}$

In the eyes of the CJEU, the compatibility of the envisaged agreement with EU law does not only depend on provisions of substantive law, such as the various EU free movement provisions, 'but also on those concerning the powers, procedure, or organization of the institutions of the Union'. ${ }^{45}$ Thus, the CJEU will agree to the creation of the ICS, only 'if the fundamental characteristics of EU law are preserved', one of them being the CJEU's own exclusive jurisdiction. ${ }^{46}$ This stems from the way in which the CJEU envisages not only the autonomy of the EU legal order vis-à-vis international law, but also the way it constructs the autonomy of its own jurisdiction. ${ }^{47}$

\section{The 'Autonomy' of the EU Legal Order and Ex-Ante Controls}

${ }^{40}$ Aliki Semertzi, 'The Preclusion of Direct Effect in the Recently Concluded EU Free Trade Agreements' (2014) 51 CMLR 1125. See also Marco Bronckers, 'Is Investor-State Dispute Settlement (ISDS) Superior to Litigation Before Domestic Courts? An EU View on Bilateral Trade Agreements’ (2015) 18 JIEL 655.

${ }^{41}$ See references in nn 38-40. See also Christian Tietje and Clemens Wackernagel, 'Enforcement of Intra-EU ICSID Awards. Multilevel Governance, Investment Tribunals and the Lost Opportunity of the Micula Arbitration’ (2015) 16 JWIT 205.

42 Armin von Bogdandy, 'Pluralism, Direct Effect, and the Ultimate Say: On the Relationship between International and Domestic Constitutional Law’ (2008) 6 Int'l J Const L 397, 398. See also David Sloss, 'Domestic Application of Treaties' in Duncan B Hollis (ed), The Oxford Guide to Treaties (OUP 2012) 367, 372-76; André Nollkaemper, 'Rethinking the Supremacy of International Law' (2010) 65 Zeitschrift für Öffentliches Recht 65.

${ }^{43}$ Daniel Halberstam, “'It’s the Autonomy, Stupid!” A Modest Defense of Opinion 2/13 on EU Accession to the ECHR, and the Way Forward' (2015) 16(1) German LJ 114.

${ }^{44}$ Stephan W Schill, 'Luxembourg Limits: Conditions for Investor-State Dispute Settlement under Future EU Investment Agreements’ in Marc Bungenberg, August Reinisch and Christian Tietje (eds), EU and Investment Agreements (Nomos 2013) 37, 40.

${ }^{45}$ Lenaerts and others (n 36) 555 with reference to several CJEU Opinions.

${ }^{46}$ Piet Eeckhout, 'Opinion 2/13 on EU Accession to the ECHR and Judicial Dialogue: Autonomy or Autarky?' (2015) 38 Fordham Int'l LJ 955, 959 and 963.

47 Tobias Lock, The European Court of Justice and International Courts (Routledge 2015) 77-81. 
This Section focuses on the arguments used by the CJEU in order to protect the 'autonomy' of EU law when assessing the compatibility with EU law of an envisaged agreement that sets up its own system of dispute settlement. It also has to be recalled that the EU is a party to international agreements, such as the United Nations Convention on the Law of the Sea (UNCLOS) or the World Trade Organisation (WTO) Agreement, which have complex international adjudicatory mechanisms. However, in the case of these agreements the CJEU either was not asked for its opinion prior to the conclusion of the agreement or the questions referred for an opinion under Article 218(11) TFEU did not address the adjudicatory mechanism. ${ }^{48}$

\subsection{Arguments Against Extra-EU Dispute Settlement Mechanisms}

The following sub-sections focus on the way in which the CJEU developed and used the 'protection of the autonomy of the EU legal order' argument in order to find incompatibilities between an envisaged international mechanism of dispute settlement and the EU legal order.

\subsubsection{The 'Fund Tribunal’ under Opinion 1/76 - Let’s Not Share Our Judges!}

Opinion $1 / 76^{49}$ concerned the conclusion of an international agreement between the then European Community (EC) plus six Member States and Switzerland. ${ }^{50}$ The objective of the Agreement was to control the surplus carriage of goods on inland waterways in the Rhine and Moselle basins by temporarily laying-up the carrying capacity in return for financial compensation.

In order to provide for the compensation a 'Fund' was envisaged with a Supervisory Board, a Board of Management and a 'Fund Tribunal'. The latter would have been composed of one Swiss judge and six judges nominated by the CJEU from among its members. The Fund Tribunal would have handled annulment proceedings against the acts of the organs of the Fund and actions for failure to act. It would have even had the power to give preliminary rulings concerning the interpretation of the envisaged agreement, and concerning the validity and interpretation of decisions taken by the organs of the Fund. ${ }^{51}$ According to the Commission's observations the jurisdiction of the Fund Tribunal would have replaced that of

\footnotetext{
${ }^{48}$ See CJEU, Opinion 2/94 (n 35). Nevertheless, the CJEU can diminish the internal effects of decisions of extra-EU bodies by not granting them direct effect.

${ }^{49}$ CJEU, Opinion 1/76 (Inland Waterways) [1977] ECR 741.

50 The Opinion is mainly known for the CJEU's expansion of the EU's implied external competences doctrine. See De Witte (n 3) 35.

${ }^{51}$ CJEU, Opinion 1/76 (n 49) para 17.
} 
the CJEU with regard to the interpretation of the envisaged Agreement or the CJEU and the Fund Tribunal would have had parallel jurisdictions in matters covered by the Agreement. ${ }^{52}$

The CJEU found the Fund Tribunal not to be compatible with EU law. First, the Court held that the a priori possibility of diverging legal interpretations 'with consequential effects on legal certainty' between the CJEU and the Fund Tribunal was not ruled out. ${ }^{53}$ Second, the Court considered that the six members of the CJEU acting on the Fund Tribunal would prejudice their positions on the Fund Tribunal or the CJEU, when the same questions were handled by one of the other courts. Furthermore, their complete impartiality when ruling on a contentious question that would have come before the CJEU was not guaranteed. ${ }^{54}$ In other words, the CJEU would not agree to an international tribunal a) that would have parallel jurisdiction with it over the same matters covered by the envisaged agreement since this could lead to diverging interpretations or b) if its own judges would have to be members of the envisaged tribunal. However, according to the CJEU, the Fund Tribunal could have been established 'on condition that judges belonging to the Court of Justice were not called upon to serve on it'. 55

For now it is also important to note that at this point in time the CJEU had not yet introduced its arguments regarding the protection of the 'autonomy of the EU legal order'. Moreover, the condition of no personal link between the CJEU and the proposed international court resurfaces in subsequent cases, while the question of jurisdiction will become one of the pillars of the ‘autonomy’ argument.

\subsubsection{EEA I - Please Do Not Affect the Autonomy of EU Law!}

The list of negative conditions was further expanded in Opinion 1/91 (EEA I). ${ }^{56}$ The Draft Agreement on the European Economic Area (EEA Agreement) between the former EC and the members of the European Free Trade Area (EFTA) envisaged the creation of the EEA Court. The EEA Court was supposed to have jurisdiction to settle disputes between the contracting parties, to settle actions concerning the surveillance procedure regarding the EFTA States, and to handle appeals concerning decisions taken by the EFTA Surveillance

\footnotetext{
52 ibid para 19.

53 ibid para 20.

54 ibid para 22.

${ }^{55}$ ibid.

${ }^{56}$ CJEU, Opinion 1/91 (n 26). For further discussion see Henry G Schermers, 'Opinion 1/91 of the Court of Justice, 14 December 1991; Opinion 1/92 of the Court of Justice, 10 April 1991' (1992) 29(5) CMLR 991; Barbara Brandtner, 'The Drama of the EEA - Comments on Opinions 1/91 and 1/92' (1992) 3(2) EJIL 300.
} 
Authority in the field of competition. ${ }^{57}$ It was also supposed to interpret the provisions of the EEA Agreement in light of the available rulings of the CJEU on primary and secondary EU law prior to the signature of the agreement. Furthermore, the various EU and EEA courts had to take into account the decisions delivered by their counterparts in order to ensure a uniform interpretation of the EEA Agreement. ${ }^{58}$ The EEA Court was supposed to be composed of eight judges with five of them coming from the CJEU.

This Opinion is noteworthy, since it marks the beginning of a new set of arguments used by the CJEU, which focuses on the protection of the autonomy of the EU legal order. The Court first highlighted that the objectives of the Treaty Establishing the European Economic Community (EEC Treaty) went beyond that of the EEA Agreement. The EEC Treaty established a new legal order with its underlying features of primacy and direct effect, while the EEA Agreement pursued more modest objectives and did not create a new legal order. ${ }^{59}$ Therefore, even if two provisions were identically worded in the EEA Agreement and the EEC Treaty, their actual meaning could differ due to the different objectives the two agreements pursued. Thus, the EEA Court could not secure their homogenous interpretation. ${ }^{60}$

The CJEU then introduced its main line of arguments based on the possibility of the proposed EEA Court to undermine the autonomy of the EU legal order. ${ }^{61}$

The first argument concerned the power of the EEA Court to settle disputes between the 'contracting parties', which could also include disputes between EU Member States or between Member States and the EU. Such a power would have adversely affected the allocation of responsibilities between the EU and its Member States as provided in the EEC Treaty. Furthermore, this would have adversely affected the autonomy of EU Law, since under Article 219 EEC Treaty (now Article 344 TFEU) the CJEU has exclusive jurisdiction over disputes arising between EU Member States that involve the application and interpretation of EU law. ${ }^{62}$

In its second argument the CJEU emphasized its interpretative powers over EU international agreements. ${ }^{63}$ Since EU international agreements are considered to be acts of the EU institutions and form an integral part of EU law, the CJEU had jurisdiction to give

\footnotetext{
${ }^{57}$ CJEU, Opinion 1/91 (n 26) para 6.

58 ibid paras 8-9.

59 ibid paras $16-21$.

${ }^{60}$ ibid paras 23-26.

61 ibid para 30.

62 ibid para 35.

63 ibid para 38.
} 
preliminary rulings on their interpretation. It could also base its ruling on the international agreement in case a Member State failed to fulfil its obligation under the agreement. However, if an envisaged agreement provided for its own system of courts with the jurisdiction to settle disputes between its contracting parties and to interpret the provisions of the agreement, such decisions of the international court would also become binding on the CJEU. ${ }^{64}$ Nevertheless, such an envisaged agreement is 'in principle' compatible with EU law; still, since the EEA Agreement covered many areas essential also to the EU legal order, the uniformity of interpretation and the homogeneity of EU law would have been upset by introducing into the EU legal order binding decisions of such fundamental EU provisions. ${ }^{65}$ In other words, the interpretation given by the international court to provisions of EU law cannot 'spill-over' into the EU legal order and bind the EU institutions, including the CJEU. ${ }^{66}$

In its third argument, the CJEU incorporated into the overall 'autonomy' argument the Opinion 1/76 requirement of not having a personal link between the CJEU and the proposed court. The CJEU was not convinced that the 'organic links' between the EEA Court and the CJEU, provided by the participation of CJEU judges in the EEA Court, ${ }^{67}$ would safeguard the autonomy of the EU legal order. This was so, since judges were supposed to interpret identical provisions of two agreements with differing objectives, while sitting on two different courts. ${ }^{68}$

The fourth argument concerned the possibility of EFTA national courts to refer questions to the CJEU on the interpretation of provisions of the EEA Agreement identical to those of the EU treaties. The Court acknowledged that nothing in the EEC Treaty prohibited it from interpreting an international agreement for the purposes of its application in non-member countries. However, it was unacceptable to the CJEU that in such a case its answers given to the EFTA national courts would have purely been advisory and non-binding. ${ }^{69}$

The Court ended its opinion by re-iterating that in principle a system of international adjudication was not incompatible with EU law, provided that it does not conflict with the CJEU's exclusive power to ensure the interpretation and application of the EU treaties and is not in conflict with the very foundations of EU law. According to Schermers, this Opinion is important because the Court took a 'strong position in accepting only one European Union

\footnotetext{
${ }^{64}$ ibid paras 38-39.

65 ibid paras 41-46.

${ }^{66}$ Schill (n 44) 50-51.

67 ibid para 47.

68 ibid paras 48-52.

69 ibid paras 59-61.
} 
law system'. ${ }^{70}$ The envisaged EEA Agreement went beyond ordinary international agreements since it directly influenced internal matters of EU law. As 'guardian' of the EU legal system, the CJEU could 'not accept that [EU legal notions] could be interpreted by courts other than the [CJEU] for the sole reason that these notions also appear under the EEA Agreement'.71

\subsubsection{The Patent Court - No Breach of Article 344 TFEU, But Incompatibilities Were} Still Found

The CJEU added 'new bricks to the 'constitutional building' of the EU' ${ }^{72}$ in its more recent Opinion 1/09. ${ }^{73}$ It concluded that the envisaged agreement between the EU, its Member States, and non-EU parties to the European Patent Convention, setting up a European and Community Patent Court (ECPC), ${ }^{74}$ was incompatible with EU law.

The ECPC would have had the jurisdiction to hear actions related to European and Community patents. ${ }^{75}$ The new court also had to respect Community law and would base its decisions on the envisaged agreement, on directly applicable EU law, the EPC and any provisions of international agreements applicable to patents. ${ }^{76}$ The ECPC would have also had exclusive jurisdiction over a set of actions relating to the granting, operation and infringement of patents. Moreover, a preliminary reference system was provided under which the envisaged court of first instance could and the court of appeal had to refer a question to the CJEU if a question of interpretation of the EC Treaty arose. ${ }^{77}$

The CJEU's first argument related to Article 262 TFEU, under which the Council of the EU in accordance with a special legislative procedure may adopt provisions that confer jurisdiction to the CJEU over disputes 'relating to the application of acts adopted on the basis of the [EU] Treaties which create European intellectual property rights'. The CJEU held that Article 262 TFEU could not preclude the creation of the ECPC since it only contemplates the possibility of extending the CJEU's jurisdiction to disputes relating to intellectual property rights, but it does not establish a monopoly of the Court over such cases. In its second

\footnotetext{
${ }^{70}$ Schermers (n 56) 1005.

${ }^{71}$ ibid 1006.

72 Roberto Baratta, 'National Courts as "Guardians” and “Ordinary Courts” of EU Law: Opinion 1/09 of the ECJ' (2011) 38(4) LIEI 297, 307.

${ }^{73}$ CJEU, Opinion 1/09 (European and Community Patent Court) [2012] ECR I-1137.

${ }^{74}$ See Kevin P Mahne, 'A Unitary Patent and Unified Patent Court for the European Union: An Analysis of Europe’s Long Standing Attempt to Create a Supranational Patent System’ (2012) 94(2) J Pat Off Soc’y 162.

${ }^{75}$ CJEU, Opinion 1/09 (n 26) paras 7-8.

76 ibid para 9.

${ }^{77}$ ibid paras 10-12.
} 
argument, the CJEU found no incompatibility with Article 344 TFEU, since the jurisdiction of the ECPC would only relate to disputes between individuals.

Nevertheless, the CJEU then introduced a new set of arguments relating to the Member States' duty of loyal cooperation under Article 4(3) TEU. ${ }^{78}$ It argued against the exclusive jurisdiction of the ECPC to handle disputes between individuals over a significant amount of potential cases concerning patents. Such a power would 'divest' the Member State courts of their jurisdiction over matters relating to patents in favour of a court set up outside the European legal system. ${ }^{79}$ Furthermore, the ECPC would not only apply and interpret provisions of the international agreement but also future and existing EU secondary and primary rules concerning patents, intellectual property, the internal market and competition law. The ECPC could also be called upon to determine a dispute pending before it in light of EU fundamental rights and principles, and it would even be capable of examining the validity of an EU act. ${ }^{80}$ Most importantly, even though the CJEU does not have jurisdiction over direct patent disputes between individuals, the Member State courts which have such jurisdiction would lose their possibility to refer preliminary questions to the CJEU, which is an essential tool for the preservation of the EU legal system. ${ }^{81}$ Moreover, if an ECPC decision were to breach EU law, that decision could not be the subject of infringement proceedings nor could it give rise to the financial liability of the Member States. ${ }^{82}$

The main argument of the CJEU revolved around the principle of sincere cooperation and the central role of Member State courts as 'guardians' of the uniform implementation of EU law, and not so much about the effects the envisaged agreement might have on the powers of the CJEU. ${ }^{83}$ According to Burgstaller, the crux of this opinion lies in the CJEU's emphasis on the importance of 'judicial dialogue' between Member State courts and the CJEU, enshrined in Article 267 TFEU. ${ }^{84}$ For the purposes of this analysis, it is important to note that the CJEU will not agree to an extra-EU system of dispute settlement which would compromise the Member States' duty of loyal cooperation. This would happen if the new extra-EU court would take over a substantial number of potential cases from Member State

\footnotetext{
78 ibid para 67-70.

${ }^{79}$ ibid para 72.

80 ibid para 78 .

${ }^{81}$ ibid paras 80-83.

82 ibid paras 88. For a criticism see De Witte (n 3) 43-44.

${ }^{83}$ Baratta (n 72) 308.

${ }^{84}$ Markus Burgstaller, 'Investor-State Arbitration in EU International Investment Agreements with Third States' (2012) 39(2) LIEI 207, 218.
} 
courts, thus 'divesting' them from the possibility to make preliminary references to the CJEU.

\subsubsection{The European Convention on Human Rights - Taking 'Autonomy' to the Next} Level

In the by now much discussed ${ }^{85}$ Opinion $2 / 13,{ }^{86}$ the CJEU held that the Agreement on the accession of the EU to the European Convention on Human Rights (ECHR), in its current form, was incompatible with EU law. It must not be forgotten that in Opinion 2/94 ${ }^{87}$ the Court had already given a negative opinion on the accession of the EU to the ECHR based on the main argument that a treaty amendment was needed given that former Article 235 EC (now Article 352 TFEU) ${ }^{88}$ could not be used as a legal basis for accession. ${ }^{89}$

The CJEU first started its analysis by providing some preliminary considerations that built on its prior Article 218(11) TFEU opinions, adding a new set of clarifications. ${ }^{90}$ It held that unlike in the times of Opinion 2/94, the provisions of primary EU law (Article 6 TEU) and those of the ECHR (Article 59 as amended) allowed for the accession of the EU to the ECHR. Even so, the CJEU emphasized that the EU treaties created a new legal order, with its own 'constitutional framework and founding principles' and it was up to the CJEU to ensure that accession would not affect the specific characteristics of the EU and EU law, such as the principle of conferral, primacy and direct effect. ${ }^{91}$ Moreover, the CJEU pointed out that all EU acts must comply with EU fundamental rights and the principle of sincere cooperation obliges Member States to ensure the respect and application of EU law. In order to preserve these specific characteristics and the autonomy of the EU legal order, the judicial system

\footnotetext{
${ }^{85}$ See Halberstam (n 43); Christoph Krenn, 'Autonomy and Effectiveness as Common Concerns: A Path to ECHR Accession After Opinion 2/13' (2015) 16(1) German LJ 147; Stian Øby Johansen, 'The Reinterpretation of TFEU Article 344 in Opinion 2/13 and Its Potential Consequences' (2015) 16(1) German LJ 169; Adam Lazowski and Ramses A Wessel, 'When Caveats Turn into Locks: Opinion 2/13 on Accession of the European Union to the ECHR' (2015) 16(1) German LJ 179; Steve Peers, 'The EU's Accession to the ECHR: The Dream Becomes a Nightmare' (2015) 16(1) German LJ 213. For other academic discussions see Editorial Comments, 'The EU's Accession to the ECHR - a “No” from the ECJ!' (2015) 52(1) CMLR 1; Eeckhout (n 46); Stephan W Schill, 'Opinion 2/13 - The End for Dispute Settlement in EU Trade and Investment Agreements?’ (2015) 16(3) JWIT 379.

${ }^{86}$ CJEU, Opinion 2/13 (n 26).

${ }^{87}$ CJEU, Opinion 2/94 (n 35).

${ }^{88}$ Article 352 TFEU provides: 'If action by the Union should prove necessary ... to attain one of the objectives set out in the Treaties, and the Treaties have not provided the necessary powers, the Council, acting unanimously on a proposal from the Commission and after obtaining the consent of the European Parliament, shall adopt the appropriate measures ...'.

${ }^{89}$ For a historical overview of the EU's attempts of accession to the ECHR, see Editorial Comments (n 85) 2-3.

${ }^{90}$ CJEU, Opinion 2/13 (n 26) paras 153-77.

91 ibid para 158.
} 
established by the EU treaties is intended to ensure consistency and uniformity in the interpretation of EU law. ${ }^{92}$

Against this background, the Court first argued that the envisaged agreement would conflict with the specific characteristics and autonomy of EU law. ${ }^{93}$ The EU would be bound by the ECHR under Article 216(2) TFEU, which would become an integral part of the EU legal order. ${ }^{94}$ This meant that the CJEU would also be subject to the decisions and the judgments of the European Court of Human Rights (ECtHR). ${ }^{95}$ Furthermore, the mechanisms under the envisaged agreement could also not bind the EU and its institutions in the exercise of their internal powers to a particular interpretation of EU law. Similarly, the ECtHR could not call into question the CJEU's findings in relation to the scope ratione materiae of EU law. Moreover, no coordination mechanism was envisaged by the Accession Agreement regarding the human rights standards under Article 53 ECHR and Article 53 EU Fundamental Rights Charter (EU Charter), and no provisions ensured that the principle of mutual trust between the Member States would not be upset. Lastly, the 'preliminary ruling' mechanism envisaged by the agreement could affect the autonomy and effectiveness of the preliminary ruling procedure under Article 267 TFEU. $^{96}$

Second, the Agreement did not provide enough guarantees that the principles enshrined in Articles 344 TFEU would not be affected. According to the CJEU, an international agreement cannot affect the allocation of powers fixed by the EU Treaties, ergo the autonomy of EU law, and the CJEU's exclusive jurisdiction in any dispute between the Member States and between the Member States and the EU. ${ }^{97}$

Third, the co-respondent mechanism was also not up to the standards required by the EU legal order, since the ECtHR's assessment of the criteria governing the attributability of an act or an omission to the EU or to the Member States would presuppose an assessment of the provisions governing the division of powers between the EU and its Member States. ${ }^{98}$

Fourth, the procedure for the prior involvement of the CJEU in a case brought before the ECtHR in which EU law was at issue would involve the ECtHR looking at whether the CJEU has already given a ruling on the same question of law. This would be tantamount to

\footnotetext{
92 ibid para 174.

93 ibid paras $178-200$

94 CJEU, Case 181/73, Haegeman v Belgium [1974] ECR 449, paras 5-6.

${ }^{95}$ CJEU, Opinion 2/13 (n 26) para 181.

96 ibid paras $184-200$.

${ }^{97}$ ibid paras 201-4.

98 ibid paras 221-24.
} 
conferring jurisdiction on the ECtHR to interpret the case-law of the CJEU. ${ }^{99}$ The situation could be remedied if the EU was fully and systematically informed in a case pending before the ECtHR. Last, the Accession Agreement would indirectly give a power of review to the ECtHR over matters of the EU's Common Foreign and Security Policy, which not even the CJEU possesses under its restricted jurisdiction in such matters. ${ }^{100}$

The arguments of the CJEU can be criticized for their somewhat formalistic approach. ${ }^{101}$ According to Eeckhout, it is clear that the conditions imposed by the CJEU in this Opinion are difficult to meet both politically and legally, ${ }^{102}$ while according to a former Judge of the ECtHR, the 'CJEU's decision was actually a political decision disguised in legal arguments'. ${ }^{103}$ Furthermore, this Opinion reveals a fundamental disagreement between the CJEU and the Member States on the desirability of EU accession to the ECHR. ${ }^{104}$

Halberstam is one of the few academics who tried providing a 'modest defense' for Opinion 2/13, urging the academic community not to forget 'about the constitutional dimension of EU governance along the way'. ${ }^{105}$ According to him, in Opinion 2/13 the CJEU took a pluralist stance on the relationship between EU and ECHR law, under which the EU's constitutional architecture need not displace all other claims of constitutional authority from within or outside of the EU. ${ }^{106}$ It is only when, norms originating in a different legal order would be capable of affecting the constitutional foundations of the EU, that the CJEU will protect the fundamental values of the EU legal order in the detriment of the extra-EU norms.

Nevertheless, in Opinion 2/13 the Court adopted a more radical version of constitutional pluralism than the softer versions ${ }^{107}$ used by the German Constitutional Court in its Solange jurisprudence ${ }^{108}$ or the ECtHR in its Bosphorus approach. ${ }^{109}$ Under this radical version of pluralism the CJEU is the only and final arbiter of EU law. This is a very important remark, since the criteria listed by the CJEU for the protection of the autonomy of EU law are not

\footnotetext{
99 ibid paras 238-39.

100 ibid paras 249-55.

${ }^{101}$ Editorial Comments (n 85) 11.

102 Eeckhout (n 46) 989.

${ }^{103}$ Graham Butler, 'A Political Decision Disguised as Legal Argument? Opinion 2/13 and European Union Accession to the European Convention on Human Rights. Interview with David Thór Björgvinsson' (2015) 31(81) Utrecht J Int'l Econ L 104, 106.

${ }^{104}$ Eeckhout (n 46) 989.

${ }^{105}$ Halberstam (n 43) 108.

106 ibid.

107 Eeckhout (n 46) 989.

108 German CC, Case BvL 52/71, Solange I [1974] BVerfGE 37, 271; Case 2 BvR 197/83, Solange II [1986] BVerfGE 73, 339; Case 2 BvR 2134, 2159/92, Maastricht Judgment [1993] BVerfGE 89, 155; Case 2 BvE 2/08, Lisbon Judgment [2009] BVerfGE 123, 267.

${ }^{109}$ Bosphorus Airways v Ireland App No 45036/98 (ECtHR, 30 June 2005).
} 
exhaustive and will be influenced by the way in which the CJEU sees its own role as the 'guardian' of the EU's constitutional legal order.

In conclusion, in Opinion 2/13 the CJEU in many ways reiterated the arguments introduced in Opinion 1/91 (EEA I), but also incorporated the developments of the last decade in cases such as Kadi $^{110}$ and Mox Plant. ${ }^{111}$ Thus, in line with Opinion 1/91, it is important that the proposed extra-EU court does not affect the CJEU's exclusive jurisdiction under Article 344 TFEU, that it does not bind the CJEU to a specific interpretation of EU law or that it does not affect the internal allocation of competences between the EU and it Member States. However, the CJEU emphasised the constitutional character of the EU legal order with its own principles, such as conferral, primacy, direct effect and sincere cooperation, which an extra-EU court must respect. ${ }^{112}$ Furthermore, due to the autonomy 'enjoyed' by EU law in relation to the laws of its Member States and international law, EU fundamental rights must be interpreted in light of the objectives of EU law, ${ }^{113}$ and the ICS cannot affect such interpretation

\subsection{No Incompatibility Between EU Law and Extra-EU Dispute Settlement Mechanisms}

It is now important to shortly focus on two cases in which the CJEU found that the 'autonomy' of EU law was not affected by the extra-EU dispute settlement mechanism.

\subsubsection{EEA II - Yes, to the EFTA Court!}

Opinion 1/92 (EEA II $)^{114}$ is the follow-up to Opinion 1/91(EEA I). The CJEU found that the modifications added to the EEA Agreement did not affect the autonomy of EU law.

First, the agreement no longer envisaged an EEA Court, which would be the ultimate supervisor of the EEA Agreement. Instead, a separate court was created only for the EFTA States, which would not hear disputes between the contracting parties and would only exercise its jurisdiction within EFTA. ${ }^{115}$ The EFTA Court also had to take into consideration

\footnotetext{
${ }^{110}$ CJEU, Kadi (n 31).

${ }^{111}$ CJEU, Mox Plant (n 33)

${ }^{112}$ CJEU, Opinion 2/13 (n 26) para 158.

113 ibid para 170 .

114 CJEU, Opinion 1/92 (EEA II) [1992] ECR I-2821. For a discussion see Schermers (n 56) and Brandtner (n 56).

115 ibid paras 4 and 19.
} 
the case-law of the CJEU prior to the signature of the Agreement and did not have any personal or functional links to the CJEU. ${ }^{116}$

Second, the Agreement set up a Joint Committee meant to ensure the homogenous interpretation of the EEA Agreement, by reviewing the development of the case-law of the CJEU and the EFTA Court, and to settle any disputes brought before it by the Community or an EFTA State regarding the application and the interpretation of the Agreement. ${ }^{117}$ The CJEU held that both procedures were compatible with EU law, since guarantees were made that the decisions of the Joint Committee made during the two procedures would not affect the case-law of the CJEU. ${ }^{118}$ Furthermore, under the new agreement the CJEU could be asked by the contracting parties to deliver an interpretation of EEA rules, which were identical to EU rules, if the Joint Committee could not settle the dispute within three months. ${ }^{119}$ According to the CJEU, an international agreement could confer new powers on it to interpret that agreement, provided the CJEU's decisions were binding. ${ }^{120}$

Third, EFTA States could authorize their courts to ask the CJEU to give a decision on the interpretation of a provision of the EEA Agreement since the answers of the Court would be binding. ${ }^{121}$ Fourth, the Agreement no longer contained any provision requiring the CJEU to pay due account to decisions of other courts. ${ }^{122}$

From the above it is fairly evident that the CJEU can agree to a system of international dispute settlement, however the conditions for doing so are quite stringent. Thus, no personal link can exist between the proposed extra-EU court and the CJEU. Furthermore, guarantees have to be made that the CJEU cannot be bound by the interpretations of EU law and the EU agreement given by an extra-EU court or body. Moreover, the CJEU will not shy away from taking on new tasks, such as ruling on the interpretation of provisions of the international agreement which are identical to those of EU law or to provide rulings on references made by the courts of non-EU contracting parties, provided such rulings are binding. Nevertheless, it can be argued that a complete institutional separation between the mechanisms overseeing the EU (CJEU) and the non-EU members (e.g. EFTA Court) is a very high guarantee that the EU's exclusive jurisdiction over EU Member States is not affected.

\footnotetext{
116 ibid para 13.

117 ibid paras 14 and 26.

118 ibid paras 23-24 and 28-29.

119 Agreement on the European Economic Area (adopted 17 March 1993, entered into force 1 January 1994) [1993] OJ L1/3 (EEA Agreement) art 111(3).

${ }^{120}$ CJEU, Opinion 1/92 (n 114) paras 32-33.

121 ibid paras 15 and 37.

122 ibid para 16.
} 
3.2.2. The European Common Aviation Area - Yes, Since the CJEU Has the Final Say Opinion $1 / 00^{123}$ concerning the legal supervision mechanism under the Agreement for a European Common Aviation Area (ECAA) between the EC, EFTA States and candidate Central and Eastern European States is more rarely discussed in legal academia. ${ }^{124}$ The envisaged agreement did not provide for a separate court; instead it conferred the exclusive jurisdiction on the CJEU to review the legality of Community decisions taken under the ECAA Agreement. Furthermore, the Agreement provided for two procedures meant to ensure the homogenous interpretation of the agreement by the Joint Committee set up under the Agreement, similar to the one in Opinion 1/92 (EEA II). Moreover, courts of non-EU contracting parties could also refer question to the CJEU on the interpretation of the agreement and the rulings of the CJEU were binding. ${ }^{125}$

The CJEU agreed to the creation of the supervisory mechanism. It noted that the agreement in many ways, even though in only one sector, was similar to the second EEA Agreement since it extended the EU acquis to non-EU States. ${ }^{126}$ The Court then held that the autonomy of the EU legal order can be considered secure if the agreement more clearly separates the EU from the other contracting parties from an institutional perspective. In other words, having two separate supervisory bodies (one for the non-EU contracting parties and one for the EU ones) offers a better guarantee for the protection of the EU legal order's autonomy. ${ }^{127}$ Nevertheless, under ECAA a 'single pillar' supervisory structure existed that extended the powers of EU institutions (mainly the Commission) over matters covered by the Agreement. Such a system could help ensure a higher level of integration between the contracting parties. $^{128}$

Based on these features the Court first concluded that the Agreement did not affect the allocation of powers between the EU and its Member States since the Member States were not parties to the agreement. This meant that the term 'contracting parties' could not be

\footnotetext{
${ }^{123}$ CJEU, Opinion 1/00 (European Common Aviation Area) [2002] ECR I-3493.

${ }^{124}$ Fernando Castillo de la Torre, 'Opinion 1/00, Proposed Agreement on the Establishment of a European Common Aviation Area’ (2002) 39(6) CMLR 1373. Other authors shortly discuss it. See Schill (n 85); Tobias Lock, 'The Future of the European Union's Accession to the European Convention on Human Rights after Opinion 2/13: Is It Possible and Is It Still Desirable?' (2015) 11(2) ECLR 239.

${ }^{125}$ CJEU, Opinion 1/00 (n 123) I-3501 and I-3502.

126 ibid para 3.

127 ibid para 6.

${ }^{128}$ ibid para 9.
} 
interpreted in a manner incompatible with EU law and no Article 344 TFEU situations would arise. $^{129}$

Second, the powers of the EU institutions were also safeguarded. The powers of the Commission were extended to third States and the CJEU was given the power to decide on the legality of decisions of the EU institutions under the agreement and to give binding preliminary rulings under the Agreement. ${ }^{130}$

Third, the uniform interpretation of ECAA was safeguarded. The Agreement provided for features similar to EU law, such as direct integration and direct effect, the possibility for preliminary references from non-EU States with binding rulings of the CJEU. Furthermore, identical provisions of the Agreement had to be interpreted in light of Commission decisions and CJEU rulings. ${ }^{131}$ Fourth, other safeguard mechanisms were very similar to those provided by the amended EEA Agreement. ${ }^{132}$

The outcome of this case followed the same logic as that in Opinion 1/92 (EEA II). In this case no extra court was created that would deliver interpretations binding on the EU. Furthermore, the EU institutions acted as the primary supervisory organs of the agreement, even as regards the non-EU contracting parties.

\subsection{Summary of the Requirements an Envisaged International Tribunal Must Meet}

It is easy to get caught up in all the minute arguments and criteria used by the CJEU when assessing the compatibility of an envisaged international dispute settlement mechanism with EU law. One, however, must not forget the broader constitutional tensions underlying the EU's and the CJEU's relationship with international law. On the one hand, the CJEU emphasises that as such, it is not against the EU's accession to an agreement having its own dispute settlement mechanism. ${ }^{133}$ On the other hand, the envisaged agreement and its dispute settlement body cannot affect the 'constitutional framework and founding principles' of the EU legal order. ${ }^{134}$ The criteria of compatibility laid down by the CJEU have become more difficult to meet and can be grouped in several categories.

The first category concerns the personal, organic or institutional links between the extra-EU court and the CJEU. As seen in Opinions 1/76 and 1/91, the CJEU will not agree to its own judges acting as judges on the extra-EU court. Furthermore, from Opinions 1/92 and

\footnotetext{
129 ibid paras $15-17$.

130 ibid paras 19-26.

131 ibid paras 27-35.

132 ibid paras 36-44.

133 CJEU, Opinion 1/91 (n 26) paras 40-70; Opinion 1/09 (n 26) para 74; Opinion 2/13 (n 26) para 182.

${ }^{134}$ CJEU, Opinion 2/13 (n 26) para 158.
} 
$1 / 00$ it can be concluded that the creation of a separate court overseeing the application of the agreement in the non-EU contracting parties is not necessary, but it is a strong guarantee for the protection of the autonomy of EU law.

The second category concerns the exclusive jurisdiction of the CJEU. This category has three sub-elements. First, the extra-EU court or dispute settlement mechanism cannot upset the Court's exclusive jurisdiction under Article 344 TFEU to handle cases involving EU Member States, when the application and interpretation of EU law is concerned. Second, the extra-EU court cannot interfere with the CJEU's exclusive jurisdiction to invalidate secondary EU law. Third, the extra-EU court cannot affect the CJEU's exclusive jurisdiction to deliver binding interpretations of EU law. Also, if a non-judicial body is set up (such as a Joint Committee), the jurisdiction of the CJEU is not affected if the interpretations provided by the Joint Committee do not affect the CJEU's case-law and are not binding on it.

The third category concerns the safeguarding of EU fundamental rights. This group of criteria became a lot more relevant after Kadi, as exemplified by Opinion 2/13 and has two facets to it. First, every EU act, even EU international agreements, must respect EU fundamental rights. Second, fundamental rights within the EU must be interpreted in light of the objectives of the EU.

Under the fourth category, as exemplified in Opinions 1/91, 2/13 and Mox Plant, the extra-EU tribunal cannot affect the internal division of competences/responsibilities between the EU and its Member States. This could happen if the extra-EU court was charged with the interpretation of the term 'contracting parties', when dealing with a mixed agreement to which both the EU and the Member States are contracting parties. Such a situation does not arise if only the EU, and not its Member States, is a contracting party to the agreement. ${ }^{135}$ Furthermore, an assessment of the EU's internal provisions on the division of powers would occur, if the extra-EU court had to decide on whether a specific act or omission is attributable to the EU or a Member State. ${ }^{136}$

The fifth category relates to the preliminary reference procedure. First, the CJEU will not find an incompatibility if an international agreement includes a preliminary reference procedure, provided that it is the CJEU that has to deliver the ruling (and not the extra-EU court as seen in Opinion 2/13) and that the ruling is binding on the extra-EU referring court. Second, as seen in Opinion 1/09, the CJEU will not agree to a system under which the Member States would transfer a significant amount of cases to the extra-EU court, thus

${ }^{135}$ CJEU, Opinion 1/00 (n 123) para 16.

${ }^{136}$ CJEU, Opinion 2/13 (n 26) paras 221-24. 
depriving themselves of the possibility to refer questions to the CJEU under those matters and breaching their duty of sincere cooperation.

The sixth category concerns other fundamental principles or values of the EU. According to Opinions $2 / 13$ and $1 / 09$, the CJEU will not agree to a system that might affect the principles of sincere cooperation, direct effect or primacy. As shall be seen, other fundamental values could also be found, which relate more to substantive issues, such as the prohibition of State aid in the EU or the prohibition of anti-competitive agreements.

\section{Not All Criteria Are Met by the Proposed ICS}

The following sub-sections will address the compatibility of the proposed ICS with the EU legal order in light of the afore-mentioned categories of criteria. The overall tension between the EU's role as an international actor and the CJEU's role as the EU's constitutional court will provide the guiding thread throughout the discussion.

\subsection{Lack of Personal or Organic Links}

An apparently simple requirement concerns the prohibition to have a personal or 'organic' link between the international tribunal and the CJEU. Judges of the CJEU cannot act as judges of the envisaged international tribunal since this would not only cause operational difficulties within the CJEU, but it could also compromise the impartiality of the CJEU judges if the same issue arose before both courts. ${ }^{137}$

According to the Proposal, the judges of the Investment Tribunal and the Appeal Tribunal would be equally divided between the EU, the United States and third States ${ }^{138}$ and shall possess the necessary qualifications laid out in Articles 9(4) and 10(7) of Section 3 of the Proposal. Moreover, their independence shall be beyond doubt and they shall not be affiliated with any government or take instructions from any government or organization. ${ }^{139}$ Thus, it is clear from these proposed provisions that judges of the CJEU do not have to also act as judges of ICS and their impartiality in the situation of a similar question appearing before both the CJEU and the ICS is guaranteed. In other words, the lack of a personal link requirement is satisfied by the proposed ICS.

\subsection{The CJEU's Exclusive Jurisdiction Might Be Affected}

\footnotetext{
${ }^{137}$ Opinion 1/76 (n 49) para 22.

138 Proposal (n 1) s 3, arts 9(2) and 10(2).

139 ibid art 11.
} 
Let us now discuss the ICS' compatibility with the three elements of the CJEU's exclusive jurisdiction: the exclusive jurisdiction to handle Member State disputes that concern EU law; the exclusive jurisdiction to invalidate EU law; and the exclusive jurisdiction to provide binding interpretations of EU law.

\subsubsection{A Conflict Between the ICS and Article 344 TFEU?}

The CJEU's Article 344 TFEU arguments, ${ }^{140}$ eloquently elaborated in Mox Plant and Opinion 2/13, on the face of it are not of concern for this analysis, since the proposed ICS would handle cases between private parties and Member States or the EU, and would not handle cases between EU Member States or Member States and the EU.

Such a conclusion seems to be strengthened by several arguments. First, the CJEU noted in Opinion 1/09 (ECPC) that Article 344 TFEU did not concern disputes between private parties since 'that article merely prohibits Member States from submitting a dispute concerning the interpretation or application of the Treaties' to extra-EU methods of dispute settlement. ${ }^{141}$ Second, the arbitral tribunal in Eureko v Slovakia held that Slovakia's reference to the interpretation of Article 344 TFEU in Mox Plant had no implications for the dispute it was seized with, since that provision did not concern investor-State disputes, but disputes between two Member States. ${ }^{142}$ The same conclusion was also reached by the Oberlandesgericht Frankfurt in the follow-up to investment arbitration under the DutchSlovak Bilateral Investment Treaty (BIT) in Eureko $v$ Slovakia. ${ }^{143}$ The Slovak Republic appealed to the German Federal Court of Justice (Bundesgerichtshof, BGH) which decided to make a reference to the CJEU on the compatibility of intra-EU BITs with Articles 344, 267 and 18 TFEU. Nonetheless, the BGH also provided its preliminary view according to which Article 344 TFEU does not rule out the possibility that a foreign investor can bring a claim against an EU Member State. ${ }^{144}$

\footnotetext{
${ }^{140}$ See Lock (n 47) 114-27.

${ }^{141}$ CJEU, Opinion 1/09 (n 26) para 63. For a further discussion on art 344 TFEU see Johansen (n 85).

142 PCA, Eureko $v$ The Slovak Republic, PCA Case No 2008-13, Award on Jurisdiction, Arbitrability and Suspension (26 October 2010) para 276.

143 Konstanze von Papp, “Clash of “Autonomous Legal Orders”: Can EU Member State Courts Bridge the Jurisdictional Divide Between Investment Tribunals and the ECJ? A Plea for Direct Referral from Investment Tribunals to the ECJ' (2013) 50 CMLR 1039, 1049-1050 with reference to OLG Frankfurt am Main, Case 26 SchH 11/10, Decision (10 May 2012) BeckRS 2012, 10291

144 Bundesgerichtshof, Case I ZB 2/15, Decision (3 March 2016) paras 30-39. For a short commentary see Herbert Smith Freehills, 'Arbitration and Intra-EU BITs - German Bundesgerichtshof Weighs in on the Discussion' (12 May 2016) <http://hsfnotes.com/arbitration/2016/05/12/arbitration-and-intra-eu-bits-germanbundesgerichtshof-weighs-in-on-the-discussion/> accessed 2 June 2016; Jan Frohloff and Max Oehm, 'Compatibility of Intra-EU BITs with EU Law' (25 May 2016) Global Arbitration News < http://globalarbitrationnews.com/compatibility-intra-eu-bits-eu-law/> accessed 2 June 2016.
} 
Von Papp, on the other hand, took a more nuanced approach to the reach of Article 344 TFEU. Under this provision, 'Member States undertake not to submit a dispute concerning the interpretation or application of the [EU] Treaties to any method of settlement other than those provided for therein.' From Mox Plant and Opinion 1/09 we know that this provision applies to Member State-Member State disputes, but does not apply to private party-private party disputes. Nevertheless, a more expansive reading of Article 344 TFEU could accommodate investor-Member State disputes, since it does not specify whether it only covers disputes involving two Member States or also disputes between Member State and a private party, such as an investor. ${ }^{145}$ Knowing how the CJEU prefers to use a more teleological approach whenever its own functions are concerned, ${ }^{146}$ one might not be surprised to find that the CJEU could conclude that Article 344 TFEU applies to investor-Member State disputes. Even so, Article 344 TFEU only lays down obligations for Member States, but not the EU. Thus, at least with regard to investor-EU disputes, the CJEU could find that Article 344 TFEU would not be affected. ${ }^{147}$

\subsubsection{The CJEU's Exclusive Jurisdiction to Invalidate EU Law}

There are two underlying concerns for the autonomy of EU law stemming from Articles 19(1) TEU and Article 267 TFEU that the drafters of the proposed ICS seem to have been aware of: the exclusive jurisdiction of the CJEU to invalidate secondary EU law ${ }^{148}$ and the exclusive jurisdiction of the CJEU to give binding interpretations of EU law.

In the context of the relationship between the CJEU and Member State courts, Moorhead has noted that two types of review exist when legal norms of different origins are concerned. ${ }^{149}$ On the one hand, 'cross-order' review concerns 'the review of legal norms originating in one order by reference to those originating in the "opposing” order'. On the

\footnotetext{
${ }^{145}$ von Papp (n 143) 1053-54.

146 See Miguel P Maduro, 'Interpreting European Law: Judicial Adjudication in a Context of Constitutional Pluralism’ (2008) 1(2) EJLS 1.

${ }^{147}$ Burgstaller (n 84) 217.

${ }^{148}$ Under Article 267(a) TFEU the CJEU can interpret the EU treaties and (b) it can rule on the validity and interpretation of secondary EU law. According to the CJEU, 'national courts do not have the power to declare acts of the European Union institutions invalid'. This stems from the need to provide a uniform application of EU law. See CJEU, Joined Cases C-143/88 and C-92/89, Zuckerfabrik Süderdithmarschen [1991] ECR I-415, para 17; Case C-6/99, Greenpeace France and Others [2000] ECR I-1651, para 54; Case C-344/04, IATA and ELFAA [2006] ECR I-403, para 27; Air Transport Association of America (n 26) para 47.

${ }^{149}$ Timothy Moorhead, The Legal Order of the European Union. The Institutional Role of the Court of Justice (Routledge 2014) 93.
} 
other hand, 'internal-order' review deals with the review of measures originating in one order against the higher norms laid down by that legal order. ${ }^{150}$

Cross order review of validity is relevant for our discussion and can occur in different ways. It is possible if a court from legal order A decides to directly review the legality of a measure from legal order $\mathrm{A}$ in light of a norm from legal order B. For example, in some Member States of the EU constitutional courts will review the validity of their national legislation in light of EU law. ${ }^{151}$ The CJEU has also conducted numerous reviews of validity of secondary EU law in light of EU international agreements. ${ }^{152}$ However, the opposite scenario is not possible. The court of legal order A cannot directly decide on the validity of a norm coming from legal order B for its non-conformity with a norm of legal order A. Thus, the CJEU has prohibited Member State courts to invalidate EU law ${ }^{153}$ and the CJEU cannot invalidate Member State or international law. ${ }^{154}$ However, the CJEU is known to have performed an indirect review of UN law in Kadi by directly reviewing an EU regulation implementing a UN Security Council Resolution for its conformity with EU fundamental rights.

In case of the CJEU, much of its Kompetenz-Kompetenz derives from the need to avoid the possibility that other courts (Member State or international) would review the validity of Union measures, thus undermining the viability of EU law as an independent source of law. In other words, the CJEU will make sure that no cross-order review of validity is possible that would lead to a court outside of the EU to review the validity of EU law. ${ }^{155}$

This criterion is met by the proposed ICS since Article 13(1) of Section 3 of the Proposal clearly limits the powers of the Investment Tribunal to finding an inconsistency between the treatment afforded to foreign investors by the host-entity (EU, Member States or the United States) and the investment protection standards provided in TTIP. Moreover, the Tribunal cannot determine the legality of the measure of the contracting parties, which is alleged to

\footnotetext{
150 ibid.

${ }^{151}$ For eg the Romanian CC under the 'interstitial rule' doctrine will take into account any rule of European law which is sufficiently clear, precise and unambiguous and proves a certain level of constitutional relevance during the constitutional review of national legislation. See Mihaela Mazilu-Babel, 'Condițiile impuse pentru folosirea unei norme de drept al Uniunii Europene în cadrul controlului de constituţionalitate' ('The Conditions a European Union Legal Norm Needs to Fulfil in the Course of Constitutional Review’) (2013) 11 Dreptul 181.

${ }^{152}$ One of the most elaborate cases is CJEU, Air Transport Association of America (n 26). However, because the CJEU considers EU international agreements to be an integral part of the EU legal order, it could be argued that this is a type of inter-ordinal review.

153 ibid para 47 - it is 'settled case-law [that] national courts do not have the power to declare acts of the European Union institutions invalid'.

${ }^{154}$ Moorhead (n 149) 94. This stems from the role of the CJEU under Article 267(b) TFEU.

155 Moorhead (n 149) ch 6 ('Union or Member State Kompetenz-Kompetenz: Constitutional Questions in the Relationship Between Union and Domestic Courts’).
} 
constitute a breach of this Agreement. ${ }^{156}$ Thus, the proposed ICS cannot invalidate EU legislation for not complying with the standards laid down in the Investment Chapter of TTIP.

\subsubsection{The CJEU's Exclusive Jurisdiction to Give Binding Interpretations of EU Law} The autonomy of the EU legal order also prevents an international agreement from conferring on an extra-EU court or other adjudicative body the power to interpret EU law in a binding fashion. The CJEU has reserved itself the monopoly to provide interpretations of EU law that are binding on the EU and its institutions. ${ }^{157}$ However, safeguarding this prerogative of the CJEU is not a straightforward matter. The main difficulty for the drafters of the ICS Proposal lies in understanding how the CJEU acts in order to safeguard the homogenous interpretation and application of EU law, and when the possibility arises for the CJEU to be bound by the interpretation of EU law made by an extra-EU tribunal or body.

First, the CJEU ensures the homogenous interpretation and application of EU law within the Member States. The need to ensure this homogeneity stems from the way in which the CJEU interprets EU law. The Court is known for consistently using a purposive and dynamic approach to the interpretation of EU law, in light of the integrationist objectives of the EU Treaties. This means, that an otherwise textually clear EU law provision might alter its meaning when interpreted in light of the objectives of the EU. ${ }^{158}$ It is for this reason that in Opinion 1/91 (EEA I) the CJEU held that even a system in which assurances were made that identical provisions of international agreements with that of the EU Treaties would be interpreted in light of CJEU case-law is not a good enough safeguard. ${ }^{159}$

The drafters of the Proposal seem to remedy this concern by adding that in proceedings before the ICS, the domestic law of the Parties shall not be part of the applicable law. Moreover, when the Tribunal is required to ascertain the meaning of a provision of domestic law as a matter of fact, it will need to follow the "prevailing interpretation of that provision made by the courts or authorities of that Party'. 160

From a formal point of view these two safeguards seem to suggest that the ICS will not upset the homogenous interpretation of EU law. However, some criticisms are warranted. According to Schreuer, investor-State tribunals will often apply three sources of law to a

\footnotetext{
${ }^{156}$ Proposal (n 1) s 3, art 13(4). See also Schill (n 85) 384.

${ }^{157}$ Lock (n 47) 80.

158 Moorhead (n 149) 77-78; Gáspár-Szilágyi (n 38) 608-15; Maduro (n 146).

${ }^{159}$ CJEU, Opinion 1/91 (n 26) paras 22-26.

${ }^{160}$ Proposal (n 1) s 3, art 13(3).
} 
dispute: the investment agreement, public international law and the domestic law of the host state. This way a balance is provided between the various sources of law. Taking EU or Member State law out of this equation might lead to the ICS not properly taking into account the importance of EU or Member State law to a specific dispute. ${ }^{161}$ Furthermore, since investor-State tribunals interpret and apply investment treaty obligations in a highly selfreferential manner, ${ }^{162}$ it is difficult to know when an arbitral tribunal interprets domestic law and when it merely applies it as facts to the case. The Iron Rhine ${ }^{163}$ case between the Netherlands and Belgium provides a good example.

In this case Belgium sought to reopen a railway line, which passed through a protected area in the Netherlands, based on a treaty it signed with the Netherlands in the $19^{\text {th }}$ century. ${ }^{164}$ An arbitral tribunal was established under the auspices of the Permanent Court of Arbitration. The parties sent a letter to the Commission, informing it that they shall comply with their Article 344 TFEU obligations, if the question of interpretation of EU law would arise. ${ }^{165}$ According to the parties' agreement, the arbitral tribunal would refer a preliminary question to the CJEU, if during the proceedings it engaged in the interpretation of EU law. ${ }^{166}$ Despite this, the arbitral tribunal ended up interpreting and applying EU law without the Commission ever launching infringement proceedings against the two countries for clearly breaching Article 344 TFEU. ${ }^{167}$ Commission v Slovak Republic, ${ }^{168}$ concerning the Swiss-Czech and Slovak BITs, is another example of how in practice even the CJEU blurs the distinction between application and interpretation. Even though the CJEU acknowledged that it was not for it to interpret the Investment Protection Agreement, the CJEU in fact ended up interpreting the Agreement when it determined that an 'investment' was made. ${ }^{169}$

While Iron Rhine and Commission v Slovakia concerned agreements to which the EU was not a party, TTIP would be a mixed agreement, concluded by the EU and its Members States on the one side, and the United States on the other. Under the CJEU's longstanding

161 Christoph H Schreuer, 'Keynote Address: The Development of International Law by ICSID Tribunals' (ICSID at 50: Investment Arbitration as a Motor of General International Law?, Frankfurt Investment Law Workshop, Frankfurt am Main, 11-12 March 2016).

162 Stephan W Schill, 'Deference in Investment Treaty Arbitration: Re-Conceptualizing the Standard of Review' (2012) 3(3) JIDS 577, 591.

${ }^{163}$ Arbitration regarding the Iron Rhine ('Ijzeren Rijn') Railway (The Kingdom of Belgium and The Kingdom of the Netherlands), Award of the Arbitral Tribunal (24 May 2005) XXVII RIAA 35.

164 ibid paras 16-25. See also Lock (n 47) 143-46; Szilárd Gáspár-Szilágyi, 'EU Member State Enforcement of “Mixed” Agreements and Access to Justice: Rethinking Direct Effect’ (2013) 40(2) LIEI 163, 179.

${ }^{165}$ Nikos Lavranos, 'The Mox Plant and Ijzeren Rijn Disputes: Which Court Is the Supreme Arbiter?' (2006) 19 Leiden J Int’l L 223, 228.

${ }^{166}$ Iron Rhine (n 163) para 103.

167 See Lavranos (n 165).

168 CJEU, Case C-264/09, Commission v Slovak Republic [2011] ECR I-8065.

169 ibid paras 40-50. See von Papp (n 143) 1055-56. 
Haegeman jurisprudence, international agreements which are binding on the EU become an integral part of the EU legal order. ${ }^{170}$ This means that the CJEU would consider TTIP as part of the EU's domestic law, the same 'domestic law' which the ICS is prohibited from interpreting in a binding fashion. Coupled with the CJEU's exclusive jurisdiction over EU law provisions, this could lead to the presumption that the 'the EU's autonomy is "threatened" every time that another body ... can render binding interpretations over EU law'. 171

According to Semertzi this circular reasoning has only an inward validity in the EU legal order and it is based on the need to ensure the uniform interpretation and application of EU law. However, this reasoning cannot be projected against international judicial bodies entrusted to ensure the contracting parties' compliance with the international agreement. ${ }^{172}$ Semertzi's arguments are accurate when the international court is already in existence, since its existence is based on an international agreement placed in the international legal order. However, in most Article 218(11) TFEU Opinions the international agreement setting up the international court is not yet in force or the EU has not yet acceded to the agreement setting up the international court. Therefore, it is still up to the contracting parties to decide whether to conclude the agreement or not, and a negative opinion of the CJEU following its afore-mentioned circular reasoning will result in the non-conclusion of the agreement.

The second important point of discussion is that only the CJEU can deliver a binding interpretation of EU law. The Proposal seems to remedy this by providing that the meaning given to the relevant domestic law by the ICS shall not be binding on the domestic courts and authorities. ${ }^{173}$ Furthermore, the Services and Investment Committee may adopt decisions interpreting the provisions of the Chapter on Investment if serious interpretational concerns arise, and such decisions shall be binding on the ICS. ${ }^{174}$

Nevertheless, it seems that the Proposal contains two conflicting international norms. On the one hand, the meanings given to EU law by the ICS would not be binding on the EU courts. On the other hand, a final award issued by the Investment Tribunal shall be binding

\footnotetext{
170 The TFEU does not provide any rules on how international law should relate to the EU legal order. Article 216(2) TFEU only provides that agreements concluded by the EU are binding on both the EU and its Member States. The direct integration of an EU international agreement in the EU's legal order is a result of the CJEU's case-law. See CJEU, Case 181/73, Haegeman v Belgium [1974] ECR I-00449, paras 5-6; Case 12/86, Demirel [1987] ECR 03719, para 7; Case C-93/02 P, Biret v Council [2003] ECR I-10497, para 60; Case C-240/09, Lesoochranárske zoskupenie v Slovak Ministry [2011] ECR I-1255, para 30.

${ }^{171}$ Semertzi (n 40) 1138.

172 ibid.

${ }_{174}^{173}$ Proposal (n 1) s 3, art 13(4).

${ }^{174}$ ibid art 13(5).
} 
between the contracting parties. ${ }^{175}$ The binding character of the awards is also strengthened by EU law. As the CJEU has held in Opinions 1/91 and 2/13, EU primary law through Article 216(2) TFEU dictates that international agreements to which the EU is a contracting party are binding on the EU institutions and the Member States. Moreover, decisions of an international court interpreting the envisaged agreement also become binding on the CJEU. ${ }^{176}$

It is difficult to see then, how in practice the ICS award would be binding on the EU and its institutions (including the CJEU) under both EU law and TTIP, but in the same time the meaning given to EU law by the ICS would not be binding. This legal 'oxymoron' seems to be exacerbated by our previous discussion on knowing when an arbitral tribunal applies or interprets EU law. Thus, the ICS might as well end up interpreting EU law, and even though formally that interpretation is not binding on the EU, the award itself is binding on the EU and its institutions, including the CJEU.

With regard to the interpretations of the agreement given by the Services and Investment Committee, the CJEU has held that a Joint-Committee set-up under an envisaged agreement and tasked with the interpretation of the agreement is compatible with EU law, provided such interpretations are not binding on the EU and the CJEU. ${ }^{177}$ This could be remedied by a clear statement to this effect.

In conclusion, the chances are fairly high that the CJEU would consider that the safeguards provided in the Proposal are not sufficient to guarantee that 'the CJEU has the ultimate authority on questions of interpretation ... of EU law’ ${ }^{178}$

\subsection{Enough Guarantees for the Protection of EU Fundamental Rights?}

One might wonder whether the drafters of the Proposal should have included a clause stating that the awards of the proposed ICS will not affect fundamental rights. In the pre-Kadi caselaw such clauses were not included in the various envisaged agreements. However, in the post-Kadi era the non-interference with EU fundamental rights by extra-EU bodies is crucial, as most recently seen in Opinion 2/13. Given the formalistic approach taken by the CJEU in its Opinion 2/13, such a clause would have been welcomed. Nevertheless, it is doubtful whether such a clause is a sufficient safeguard. As concluded above in Section 3.3, the criterion of non-interference with EU fundamental rights has two facets to it. On the one hand, all EU acts (including EU international agreements) must be in conformity with EU

\footnotetext{
175 ibid arts 13(4) and 30.

${ }^{176}$ CJEU, Opinion 1/91 (n 26) para 37.

${ }_{177}$ CJEU, Opinion 1/00 (n 123) para 39.

${ }^{178}$ De Witte (n 3) 34.
} 
fundamental rights. On the other hand, EU fundamental rights must be interpreted in light of the objectives of the EU and extra-EU tribunals cannot affect their interpretation.

With regard to the conformity of the Proposal with EU fundamental rights, the CJEU might find a conflict between Article 30 of Section 3 of the Proposal and the right to fair trial and effective remedies. Under this provision, final awards issued by the ICS shall not be subject to appeal, review, set-aside, annulment or any other remedy. The CJEU could view this as an infringement of the right to a fair trial and effective remedies, protected by Article 47 of the EU Charter of Fundamental Rights.

Concerning the interpretation of EU fundamental rights, the situation is trickier. A potential conflict might exist with the right to property as protected under Article 17 of the EU Charter. This article provides a set of minimum standards, such as the prohibition to interfere with the right to property, except in the public interest, subject to fair compensation. According to Dimopoulos typical BIT provisions on expropriation and compensation offer at least equivalent protection to EU primary law standards. Nevertheless, incompatibilities might arise between secondary EU law and EU investment agreements over the interpretation of what constitutes 'fair' compensation. ${ }^{179}$

Furthermore, if the Investment Tribunal concludes that the treatment afforded by the host-entity breaches the standards laid down in the current Proposal, such as the prohibition of expropriation, it may award on the basis of a request from the claimant monetary damages and applicable interests or the restitution of property against the EU or the Member States. ${ }^{180}$ This, however, could come into conflict with how limitations to EU fundamental rights are interpreted in light of the objectives of the EU. In other words, an EU or Member State action or measure which might be deemed to be compensable by the ICS, since it constitutes indirect expropriation, could be justifiable under EU law on public policy grounds. ${ }^{181}$

As von Papp has argued, in the EU legal order EU public policy trumps whatever decision arbitrators have made. The Eco Swiss line of cases holds that EU competition law as a whole, or parts of it, is 'sufficiently fundamental for the internal market as to trigger the application of a public policy exemption under domestic law'. ${ }^{182}$ The problem is that we

\footnotetext{
${ }^{179}$ Angelos Dimopoulos, 'The Compatibility of Future EU Investment Agreements with EU Law' (2012) 39(4) LIEI 447, 464-65.

${ }^{180}$ Proposal (n 1) s 3, art 28. The Tribunal cannot order the repeal, cessation or modification of the treatment concerned, and it may not award punitive damages or monetary damages greater than the loss suffered.

${ }^{181}$ See also Olivier van der Haegen, 'European Public Policy in Commercial Arbitration: Bridge Over Troubled Water?' (2009) 16(4) MJ 449.

182 von Papp (n 143) 1056.
} 
simply do not know what the outer limits of EU public policy are. ${ }^{183}$ This is a crucial point since after the Lisbon Treaty, issues concerning foreign direct investment fall under exclusive EU competence. ${ }^{184}$ This means that the CJEU could argue that its exclusive jurisdiction to give binding interpretations of EU law, more specifically on what constitute justifiable takings of property in light of EU public policy, might be jeopardized by the proposed ICS.

For now it can be concluded that the CJEU might object to the ICS' possible interference with the right to property and the right to fair trial and effective remedies.

\subsection{The Division of EU Internal Competences and Responsibility}

Another important criterion in the CJEU's assessment is whether the proposed extra-EU tribunal would affect the internal division of competences within the EU. This could occur in two different situations: first, if the extra-EU court would apply or interpret the term 'contracting parties' under the agreement in 'such a way as to define the respective powers of the Member States' and the [EU]'; ${ }^{185}$ second, if the extra-EU court would need to decide on whether a specific act or omission is attributable to the EU or a Member State. ${ }^{186}$

When the EU decides to conclude an international agreement, slight adaptations to its internal institutional provisions can occur, such as in Opinion 1/00, when the CJEU agreed that under certain circumstances an international agreement could expand the powers of the CJEU. Nevertheless, alterations to the EU's basic constitutional principles will not be allowed, one of them being the principle of conferral. ${ }^{187}$ The Member States have conferred competences on the EU to 'attain objectives they have in common' ${ }^{188}$ This principle has implications not only internally, when it has to be decided whether the EU or the Member States are competent to act in a certain field, but also externally. In this latter case the principle of conferral helps to decide whether the EU, the Member States or both are competent to act externally, as well as, whether the EU, the Member States or both are responsible for failing to abide by their international obligations.

Schill has argued that any dispute settlement body set up under an EU investment agreement would need to make sure that it would not directly or indirectly review the

\footnotetext{
183 See Tena Hoško, 'Public Policy as an Exception to Free Movement Within the Internal Market and the European Judicial Area: A Comparison’ (2010) 10 CYELP 189, 199-201.

184 art 207(1) TFEU.

${ }^{185}$ CJEU, Opinion 1/00 (n 123) para 16.

${ }^{186}$ CJEU, Opinion 2/13 (n 26) paras 221-24.

${ }^{187}$ See also de la Torre (n 124) 1381.

188 art 1 TEU; See also art 4(1) TEU: ‘... competences not conferred upon the Union in the Treaties remain with the Member States'.
} 
distribution of competences between the EU and its Member States, when determining the proper respondent or the distribution of responsibility. ${ }^{189}$ A possible conflict between the ICS and the EU's internal division of competences can be avoided in two different ways.

First, the international agreement only includes the EU as the contracting party on the one side, without the Member States. ${ }^{190}$ This way the arbitral tribunal would not have to interpret the term 'contracting parties'. However, Member States still retain some of their competences over parts of TTIP. Therefore, TTIP shall be concluded as a mixed agreement leading to the problem of determining the respondent in case of a breach of the investment protection standards provided by TTIP. ${ }^{191}$

Second, a mechanism such as the one under the Energy Charter Treaty could be used, 'which enables the EU and its Member States, upon a request by a private investor' to decide in a given amount of time who 'is responsible in a given case and will be the respondent party to arbitration proceedings'. ${ }^{192}$ This is the option preferred in the ICS Proposal; the claimant 'shall deliver a notice to the European Union requesting a determination of the respondent', prior to bringing a claim before the Investment Tribunal. The EU, after having made a determination of the respondent, shall inform the claimant within 60 days of the receipt of the notice as to whether the EU or a Member State shall be the respondent. ${ }^{193}$ The Investment Tribunal is bound by this determination. ${ }^{194}$

The CJEU would most probably find this solution compatible with EU law since an extra-EU tribunal would not have to decide on the responsibility of the EU or the Member States and risk upsetting the internal division of competences within the EU and the principle of conferral. ${ }^{195}$

\subsection{Lack of a Preliminary Reference Mechanism}

The CJEU will agree to a system of international adjudication, which allows extra-EU courts to refer a question to the CJEU when confronted with the interpretation of EU law, if the

\footnotetext{
${ }^{189}$ Schill (n 85) 384. Internally, the EU has adopted Regulation 912/2014 which is meant to attribute financial responsibility between the EU and Member States when confronted with ISDS under EU investment agreements. However, the Regulation is 'neither sufficient nor always appropriate' to guarantee legal certainty when it comes to the EU's involvement in ISDS. See Angelos Dimopoulos, 'The Involvement of the EU in Investor-State Dispute Settlement: A Question of Responsibilities’ (2014) 51(6) CMLR 1671, 1673.

${ }^{190} \mathrm{CJEU}$, Opinion 1/00 (n 123) para 16.

${ }^{191}$ Even though the Commission has recently requested an Article 218(11) Opinion to determine who should conclude the EU-Singapore Free Trade Agreement.

${ }^{192}$ Dimopoulos (n 179) 470, with reference to the declaration attached by the EU to Article 26(3)(b)(ii) Energy Charter Treaty.

${ }^{193}$ Proposal (n 1) s 3, art 5(1)-(3).

${ }^{194}$ ibid art 5(5).

${ }^{195}$ See Schill (n 44) 49-50.
} 
CJEU's subsequent ruling is binding on the referring tribunal. ${ }^{196}$ According to Schill the introduction of a preliminary reference procedure in ISDS mechanisms would forge a coalition between the investor-State tribunal and the CJEU. Nevertheless, he argues that it is questionable whether such a mechanism is necessary. Investor-State tribunals would not need to interpret EU law or determine the conformity of EU law with the applicable EU agreement, because the ISDS mechanism is only there to determine whether the protection offered to foreign investors meets the standards laid down in the international agreement. ${ }^{197}$ Furthermore, in the case of non-ICSID arbitration held in an EU Member States, the domestic courts exercise supervisory powers over arbitral tribunals in set-aside and enforcement proceedings and can refer a question to the CJEU. ${ }^{198}$ Several comments are warranted.

As a first comment, nowhere in the Proposal is a preliminary reference mechanism envisaged and it is not entirely sure whether the CJEU would accept a preliminary question from the ICS. One pertinent issue is that of the location of the referring court. Article 267 TFEU mentions only the courts or tribunals of Member States, suggesting that only intra-EU courts can refer questions to the CJEU. This view seems to be strengthened by Miles and Others $v$ European Schools ${ }^{199}$ in which the CJEU refused a reference from the Complaints Board of European Schools, arguing that this international litigation body was located outside both the EU and the domestic systems. ${ }^{200}$ Burgstaller is also sceptical whether investor-State tribunals could be reconciled with the European Schools judgment. ${ }^{201}$ However, such a conclusion seems to ignore the CJEU's open approach to extra-EU courts in Opinions 1/91 and 1/00. According to the CJEU, courts or tribunals other than those of Member States could refer questions to it for a preliminary ruling 'provided the answers given by it were binding on the referring courts' ${ }^{202}$ Thus, the location of the ICS should not matter, as long as the answers provided by the CJEU are binding on it. This condition, however, would be difficult to accept by the other contracting party, the United States.

Another pertinent issue is whether arbitral tribunals can make a preliminary reference to the CJEU at all. Under the Court's Nordsee jurisprudence, ${ }^{203}$ domestic arbitral tribunals cannot make preliminary references to the CJEU if the parties are not legally or actually

\footnotetext{
${ }^{196}$ CJEU, Opinion 1/92 (n 114) para 37.

197 Schill (n 85) 386-87.

198 Schill (n 44) 52. For a similar argument see Bundesgerichtshof (n 144) paras 53-55; CJEU, Case C-126/97, Eco Swiss China Time Ltd v Benneton International NV (Eco Swiss) [1999] ECR I-3055, paras 35-37.

${ }^{199}$ CJEU, C-196/09, Miles and Others v European Schools [2011] ECR I-5105.

${ }^{200}$ Baratta (n 72) 317 with reference to CJEU, European Schools (n 199) paras 37-39 and 42.

${ }^{201}$ Burgstaller (n 84) 220.

${ }^{202}$ CJEU, Opinion 1/91 (n 26) paras 59-65; CJEU, Opinion 1/00 (n 123) para 33.

${ }^{203}$ Case 102/81, Nordsee v Reederei [1982] ECR 01095.
} 
obliged to have their dispute decided by arbitration, and if the authorities of the Member State in question are neither involved in the arbitral decision, nor required to intervene automatically. ${ }^{204}$ Thus, domestic arbitral tribunals are not in a position analogous to domestic courts, even though they do decide on domestic issues as well. ${ }^{205}$ Nevertheless, if the parties cannot influence the jurisdiction and set-up of the arbitral tribunal, the CJEU will regard it as a court or tribunal under Article 267 TFEU. ${ }^{206}$ In this latter scenario a domestic arbitral tribunal could refer a question to the CJEU and the Court's ruling would bind it. ${ }^{207}$

The question is whether the proposed ICS meets these conditions. With regard to its set-up, the ICS meets the Nordsee condition since it functions as a standing court system, with a fixed number of appointed judges. Nevertheless, Nordsee also requires the tribunal's jurisdiction to be mandatory and exclusive. In other words, 'parties are obliged to use that judicial body as opposed to any other' ${ }^{208}$ However, the ICS' jurisdiction is neither mandatory nor exclusive. The claimant may submit a claim to the Tribunal ${ }^{209}$ and the Tribunal shall dismiss identical claims submitted before it or any other domestic or international court. ${ }^{210}$ Von Papp, on the other hand, argues that de facto the jurisdiction of an investor-State tribunal should be considered as being mandatory, since an investor that wants a neutral forum for challenging the legality of acts by the host State, must bring the case before an investment tribunal. ${ }^{211}$ This argumentation is not without criticism. The statement on 'neutrality' undermines the role of national courts as neutral forums of adjudication, even when their own governments' measures are concerned. Such a statement could lead to a dangerous presumption of national courts being biased.

As a second comment, it is very difficult to draw a clear line between the application and interpretation of EU law to a specific scenario by the proposed ICS, and the mere finding that the investor's standards of protection have been breached. Therefore, for the interest of legal certainty, a preliminary reference procedure would have been welcomed.

As a third comment, a preliminary reference procedure under TTIP is necessary because the role of EU Member State courts in set-aside and enforcement proceedings of ICS awards

\footnotetext{
${ }^{204}$ Morten Broberg and Niels Fenger, Preliminary Reference to the European Court of Justice (OUP 2010$) 84$.

${ }^{205}$ Lock (n 47) 145.

206 Case 109/88, Handels og Kontorfunktioncerernes Forbund i Danmark (Danfoss) [1989] ECR 03199, paras 7-8; Case C-400/93, Royal Copenhagen [1995] ECR I-1275.

${ }^{207}$ Case 54/76, Benedetti v Munari [1977] ECR 163.

208 von Papp (n 143) 1069.

${ }^{209}$ Proposal (n 1) s 3, art 6(1).

${ }^{210}$ ibid art 14(1). The Proposal includes other safety clauses on forum shopping (art 15), such as the prohibition of disputes brought by claimants who had acquired ownership or control of the investment for the main purpose of submitting a claim before the ICS.

${ }^{211}$ See von Papp (n 143) 1069 and 1070-71.
} 
would be minimal. The Proposal provides for arbitration under the rules of ICSID, among others. $^{212}$ Furthermore, regardless of the arbitration rules used in the proceedings, final awards of the ICS would not be subject to any further review, appeal, set-aside or annulment. $^{213}$ Therefore, the possibility for preliminary references from EU Member State courts concerning ICS awards would be minimal.

The arguments that should be put forward in favour of the CJEU accepting a preliminary reference from the ICS are of a broader nature. First, the Nordsee line of cases all concerned domestic commercial arbitral tribunals. The ICS, on the other hand, would have to decide on measures of Member States or the EU that most often entail the usage of public and regulatory powers. Therefore, commercial arbitral tribunals and the ICS are not in a comparable situation and different conditions should apply to them when deciding whether they can make a reference to the CJEU. Second, given the importance of maintaining the homogenous interpretation and application of EU law, the CJEU could open a venue for judicial dialogue in order to guide the ICS in its usage of EU law. ${ }^{214}$

In conclusion, it is doubtful whether the CJEU would agree to the ICS, given that no preliminary reference mechanism is envisaged with a binding ruling of the CJEU. This could be remedied by providing for a preliminary reference mechanism with binding rulings of the CJEU. Nevertheless, the United States would have to agree to such a mechanism. Furthermore, it is uncertain whether the Tribunal and the Appeal Tribunal would qualify as courts under Article 267 TFEU.

\subsection{Other Fundamental EU Values and Principles Might Be Affected}

The underlying thread of this article is the dilemma faced by the CJEU to protect and uphold the EU's own 'constitutional values', while also complying with the EU's constitutional requirement for an open attitude towards international law. The difficulty lies in first knowing what type of 'constitution' the CJEU has in mind and what principles, features or values of the EU legal order belong to it. According to De la Torre the CJEU in its Article 218(11) TFEU Opinions uses both the concepts of a 'rigid' and a 'material' constitution. ${ }^{215}$ Thus, the compatibility of the envisaged agreement is not only examined in light of specific articles of

\footnotetext{
${ }^{212}$ Proposal (n 1) s 3, art 6(2).

213 ibid art 30.

${ }^{214}$ For a discussion on the impact of preliminary references in the intra-EU context, see Steffen Hildelang, 'Circumventing Primacy of EU Law and the CJEU's Judicial Monopoly by Resorting to Dispute Resolution Mechanisms Provided for in Inter-Se Treaties? The Case of Intra-EU Investment Arbitration’ (2012) 39(2) LIEI 179, 196-99.

${ }^{215}$ de la Torre (n 124) 1381.
} 
the EU Treaties, but they are also examined in light of other fundamental values, such as EU fundamental rights, the internal division of competences and the CJEU's exclusive jurisdiction. The previously examined Opinions also include among the fundamental characteristics of the EU the principles of conferral, supremacy and direct effect. ${ }^{216}$

However, the list of fundamental values is not exhaustive. In Eco Swiss ${ }^{217}$ the CJEU held that former Article 85 EC Treaty (now Article 101 TFEU), concerning anti-competitive agreements, 'constitutes a fundamental provision which is essential for the accomplishment of the tasks entrusted to the [EU] and, in particular, for the functioning of the internal market'. ${ }^{218}$ As the recent Micula saga ${ }^{219}$ illustrates, EU state aid law can also become a 'thorny' issue between EU and investment law. Even though under EU law the benefits given to the investors by the Romanian authorities amount to illegal state aid, the ICSID tribunal set-up under the Sweden-Romania (now intra-EU) BIT decided against the host State.

Some of the safeguards included in the Proposal might diminish the possibility of another Micula type case under TTIP. Article 2(1) of Section 2 of the Proposal acknowledges the right of the contracting parties to regulate through measures necessary to achieve legitimate policy objectives. Moreover, possibly as a result of the Micula incident, according to Article 2(3) of Section 2, the decision of a contracting party not to issue, renew or maintain a subsidy shall not constitute a breach of the provisions on investment protection. While this carve-out might be a sufficient guarantee for state aid, what about the previously mentioned 'legitimate policy objectives'? Article 13(3) of Section 3 of the Proposal authorizes the Investment and Services Committee to adopt decisions on the interpretation of the provisions relating to Investment Protection in Section 2. Thus, this Committee could ensure that the public policy objectives of the EU are given an interpretation which the ICS is bound to follow. ${ }^{220}$ Nevertheless, such an interpretation cannot be binding on the CJEU.

For now it can be concluded that the CJEU's list of fundamental values a proposed international court has to respect is not an exhaustive one. The CJEU will not only find an

\footnotetext{
${ }^{216}$ CJEU, Opinion 2/13 (n 26) para 158.

${ }^{217}$ CJEU, Eco Swiss (n 198).

218 ibid para 36.

${ }^{219}$ This saga includes the ICSID arbitrations in Ioan Micula, Viorel Micula and Others $v$ Romania, ICSID Case No ARB/14/29 and Ioan Micula, Viorel Micula and others $v$ Romania, ICSID Case No ARB/05/20, cases pending before the General Court of the EU in Cases T-704/15, Micula and Others $v$ Commission, T-694/15, Micula $v$ Commission and T-646/14, Micula and Others $v$ Commission, and cases before various domestic courts, including the Constitutional Court of Romania, Micula and Others (File No 1214D/2015), Decision No 887 (15 December 2016), the Southern District Court of New York, Micula et al v The Government of Romania (No.1:2015mc00107), Opinion and Order (5 August 2015) and the DC District Court, Micula v Government of Romania (No1:2014cv00600). See also Tietje and Wackernagel (n 41).

${ }^{220}$ Proposal (n 1) s 3, art 13(5).
} 
incompatibility with general principles of EU law concerning the EU's constitutional architecture, but incompatibilities could occur with substantive provisions of EU law, such as the ones on the internal market and competition law. This could lead to a number of possible incompatibilities. The Investment and Services Committee's powers to provide binding interpretations of domestic law to the ICS could be a sufficient safeguard, provided such interpretations are not binding on the CJEU.

\section{Concluding Recommendations}

Following this lengthy analysis, the reader is interested in knowing the answers to two important questions: a) Would the CJEU find that the proposed ICS is compatible with EU law if asked to deliver an opinion under Article 218(11) TFEU?; and b) If the answer is in the negative, what should be changed?

As discussed, the categories of criteria laid down by the CJEU are not exhaustive and have to be seen in light of the CJEU's role as protector of the EU's constitutional legal order. Given the CJEU's and the EU political institutions' recent restrictive attitudes towards international law, the task of the drafters seems enormous. One might pose the question whether the drafters can create an ISDS mechanism, which meets the exigencies of the CJEU, but at the same time remains a self-standing tribunal with powers over EU actions and measures, unlike the EFTA Court or the ECAA dispute settlement mechanism.

A political way out from a possible negative opinion of the CJEU would be to simply not ask for an Opinion under Article 218(11) TFEU on the compatibility of the ICS with EU law. This has already been done when the EU acceded to UNCLOS and the WTO Agreement. However, such a solution would be undesirable for several reasons. First, it would not foster dialogue between the various EU institutions and it could lead to future, ex post incompatibilities between ICS awards and EU law. Second, given the often opposing interests of the Commission, the Parliament, the Council and the Member States, it is difficult to think that none of these actors would ask for an opinion. Therefore, it is necessary to sum up whether the various criteria set out by the CJEU are met by the ICS and if not, what changes could be made.

The lack of a personal or organic link requirement between the ICS and the CJEU is met. Judges of the CJEU do not have to serve on the ICS, thus their impartiality in cases which would arise before both courts would not be compromised.

Moving on, the CJEU's exclusive jurisdiction is, however, partially affected. The safeguards provided by the ICS are sufficient to protect the CJEU's exclusive jurisdiction to 
invalidate EU law, since the ICS is prohibited from reviewing the legality of domestic laws. Nevertheless, an incompatibility might arise with the CJEU's exclusive jurisdiction under Article 344 TFEU, since we do not yet know whether investor-Member State disputes are covered by this provision. A clause allowing the ICS to make a preliminary reference to the CJEU could be inserted. However, it is still up to the CJEU to decide whether the ICS is covered by Article 344 TFEU and whether it could make a preliminary reference. Furthermore, the CJEU's exclusive jurisdiction to deliver binding interpretations of EU law is also not properly safeguarded. The Proposal creates a legal 'oxymoron': the ICS can only apply EU law as facts to the case and it cannot provide binding interpretations of domestic law, but in the same time the awards delivered by the ICS shall be binding on the contracting parties both under the Proposal and EU law. Moreover, it is also difficult to know when arbitral tribunals apply or interpret domestic law. Two possible remedies might exist. Article 30(2) of Section 3 of the Proposal concerning the binding character of ICS awards could be removed. This way the above-discussed legal 'oxymoron' would not occur. Furthermore, a preliminary reference system could be included. This way the homogenous interpretation of EU law is safeguarded. However, it is difficult to see how the United States would agree to any of these solutions, which would require the CJEU taking over the role of main interpreter of the Investment Chapter under TTIP, while the lack of an express statement on the binding character of the ICS' award would risk affecting the enforceability of the award.

EU fundamental rights also need more safeguards. As explained, the CJEU could find incompatibilities with the right to an effective trial and judicial remedies, the right to property and the CJEU's jurisdiction to interpret EU fundamental rights. Article 30(1) of Section 3 of the Proposal, relating to the impossibility of having any means of recourse against a final ICS award, could be deleted to allow domestic review in cases of conflicts with domestic public policy. However, it seems difficult to imagine that the United States would agree to such a solution in light of the Beef Hormones and EC Bananas saga in the WTO. ${ }^{221}$ Furthermore, the

\footnotetext{
${ }^{221}$ The EU refused to comply with the WTO Appellate Body's reports and the CJEU refused to grant WTO law direct effect in EU law, making the possibility for private parties to seek domestic remedies against the WTO incompatible EU measures impossible or excessively difficult. For the cases before the WTO see European Communities: Measures Concerning Meat and Meat Products (Hormones) - Report of the Appellate Body (16 January 1998) WT/DS26/AB/R and WT/DS48/AB/R; European Communities: Regime for the Importation, Sale and Distribution of Bananas - Report of the Panel (22 May 1997) WT/DS27/R, modified by European Communities: Regime for the Importation, Sale and Distribution of Bananas - Report of the Appellate Body (EC - Bananas III) (9 September 1997) WT/DS27/AB/R. For the cases before the CJEU see Cases C-280/93, Germany v Council (Bananas I) [1994] ECR I-4973; C-122/95, Germany v Council (Bananas II) [1998] ECR I-999. See Geert A Zonnekeyn, 'EC Liability for Non-Implementation of Adopted WTO Panel and Appellate
} 
possibility to review ICS awards would defeat the purpose of ISDS. One solution would be to expressly provide the Joint Committee with the power to deliver interpretations on such issues as expropriation, public policy, which would be binding on the ICS, but not on domestic courts. A preliminary ruling system could also be a solution.

The EU's internal division of competences is sufficiently safeguarded in the Proposal. Following the notice of the claimant, it is up to the EU and its Member States according to their internal rules to decide whether the EU or a Member State is responsible in a given case. This means that the ICS would not have to decide on the sensitive issue of attributability, thus upsetting the EU's internal division of competences.

Unfortunately, no preliminary reference mechanism is envisaged with a binding ruling of the CJEU and even if such a system were included, it is uncertain whether the ICS would qualify as a court under Article 267 TFEU. Moreover, an incompatibility could be found with other fundamental values of EU law, such as EU competition law or EU public policy. The inclusion of such a preliminary reference mechanism would be welcome in order to ensure dialogue between the ICS and the CJEU. It would furthermore safeguard the homogenous interpretation of EU law, including matters such as EU public policy and fundamental rights.

Even with these recommendations it is not yet clear whether in light of its increasingly exigent criteria, the CJEU would agree to a type of ICS which would still have the characteristics of an investor-State tribunal. Even if by some miracle civil society, the corporate world, the United States and the CJEU would agree to the ICS, one would still be faced with possible ex post reviews if the ICS awards would conflict with EU law, or with the difficulties of domestically enforcing ICS awards.

Body Reports - The Example of the "Innocent Exporters" in the Banana Case' in Geert A Zonnekeyn, Direct Effect of WTO Law (Cameron May 2008) 134. 